\title{
The Five Presidents' Report: An Assessment of the Measures Proposed to Complete Europe's Economic and Monetary Union
}

\author{
MICHAEL WHITEMAN \\ Monash University, Melbourne, Australia \\ mpmwhiteman@yahoo.com.au
}

\begin{abstract}
The Five Presidents' Report presents a range of actions to complete Europe's Economic and Monetary Union. This article examines whether the Five Presidents' Report will lead to significant beneficial reforms, having regard to the European sovereign debt crisis and the legal framework of the Economic and Monetary Union (EMU). The article discusses the background to the production of the Five Presidents' Report, including how preceding reports responded to the European sovereign debt crisis. The proposals to create a European Deposit Insurance Scheme (EDIS), European Fiscal Board (EFB) and a Eurozone Treasury are focussed upon in this article. The article concludes that the measures proposed in the report do not go far enough towards establishing financial stability in the Eurozone. A key criticism is that counter-cyclical policy has not been the focus of the report's recommendations on fiscal matters.
\end{abstract}

Keywords: European Union, Economic and Monetary Union, Deposit Insurance Scheme, Fiscal Board, Treasury

\section{Introduction}

The 'Five Presidents' Report', released in J une 2015, presents a range of actions to complete 'Europe's Economic and Monetary Union'. 'The report was prepared by the President of the European Commission, in close co-operation with the Presidents of the Euro Summit, Eurogroup, European Central Bank (ECB) and the European Parliament. ${ }^{2}$ It is the vision of the report that the measures proposed will provide the citizens of the Eurozone a 'stable and prosperous place' that is also attractive for other European Union (EU) member states to join if they are ready to do so. ${ }^{3}$

The aim of this essay is to assess whether the Five Presidents' Report will lead to significant beneficial reforms, having regard to the European sovereign debt crisis and the legal framework of the Economic and Monetary Union (EMU). The first section of this essay details the background to the production of the Five Presidents' Report, including how preceding reports responded to the European sovereign debt

\footnotetext{
${ }^{1}$ J ean-Claude J uncker et al, Completing Europe's Economic and Monetary Union (22 J une 2015).

${ }^{2}$ Ibid, J uncker et al, 2015, p.2.

${ }^{3}$ Ibid, J uncker et al, 2015, p.5.
} 
crisis. The second section of this essay will analyse three of the more contentious actions that have been proposed. The proposals to create a European Deposit Insurance Scheme (EDIS), European Fiscal Board (EFB) and a Eurozone Treasury will be analysed. The final section of this paper presents an overall assessment of the Five Presidents' Report, including whether actions are absent from the report that should have been included.

It is submitted that the measures proposed in the Five Presidents' Report do not go far enough towards restructuring the legal framework of the EMU to ensure that financial stability in the Eurozone is maintained. In particular, a key criticism of the report is that counter-cyclical policy has not been the focus of the report's recommendations on fiscal matters. However, given the likely opposition of countries, such as Germany, towards measures that transfer sovereignty to the EU, the report's measured approach at least provides some momentum towards the process of reforming the economic architecture of the Eurozone.

\section{The European Sovereign Debt Crisis}

In October 2009, almost two years after the commencement of the global financial crisis, the newly elected Greek Government announced a revised national budget deficit of 12.7 per cent of its Gross Domestic Product (GDP). The revised figure was over double the 6.0 per cent of GDP deficit that had been estimated by the previous government. ${ }^{4}$ This event marked the beginning of the European sovereign debt crisis. ${ }^{5}$ Greece's fiscal accounts for previous years were also revised and demonstrated that Greece's previous annual deficits were also significantly larger than had been reported $^{6}$. The revelation that Greece had manipulated its budgetary figures in 2001 upon its accession to the Eurozone played an important role in the political narrative of the European sovereign debt crisis at that time ${ }^{7}$. The primary blame for the crisis was placed upon the fiscal irresponsibility of those nations, such as Greece, who experienced the greatest impacts ${ }^{8}$.

It is submitted that underlying financial and macroeconomic imbalances, rather than the irresponsibility of the Greek Government, were more significant factors behind the economic problems that plagued Greece ${ }^{9}$. The global impact of the United States subprime mortgage market crisis was a major contributor to the deficit announced by the Greek Government in 2009 ${ }^{10}$. After 2007, the tax incomes of European nations plummeted, while additional spending was required by governments for bank bailouts, refinancing, stimulus packages and social security benefits for the unemployed. ${ }^{11}$

In the spring of 2010, interest rates for Greek bonds rose to unsustainable levels, and it became apparent that Greece would lose access to market financing ${ }^{12}$. As Greece

\footnotetext{
${ }^{4}$ Philip Lane, 'The European Sovereign Debt Crisis' (2012) 26J ournal of Economic Perspectives 49, 56.

${ }^{5}$ Christoph Herrmann, 'Legal Aspects of the European Sovereign Debt Crisis' 41(2013) Hitotsubashi J ournal of Law and Politics 25, p.26.

${ }^{6}$ Lane, 2012, above n 4, p.56.

${ }^{7}$ Herrmann, 2013, above n 5, p.26.

${ }^{8}$ Lane, 2012, above n 4, p.56.

${ }^{9}$ Ibid, Lane, 2012, p.56.

${ }^{10}$ Herrmann, 2013, above n 5, 26.

${ }^{11}$ Ibid, Hermann, 2013, p.26.

${ }^{12}$ Lane, 2012, above n 4, pp.56-57.
} 
was a Eurozone Member Nation, it did not have the option of printing money (and consequently devaluing its currency), in order to prevent default. ${ }^{13}$ While withdrawal from the Eurozone may have presented a potential option to re-establish monetary sovereignty, this action would have been legally troublesome. Whereas Article 50 of the Treaty on European Union (TEU) contains a never before implemented or invoked provision for a nation's withdrawal from the EU, the treaties are silent on the subject of a state exiting the Eurozone ${ }^{14}$. It would also have been likely that extreme resistance would have been provided against such a move by other Eurozone nations, due to the potential impact such an action would have had upon the value of the euro $^{15}$.

A rescue package for Greece was subsequently implemented by the Eurozone Member States and the International Monetary Fund (IMF), which included 110 billion euro of bilateral loans. ${ }^{16}$ The temporary European Financial Stability Facility (EFSF), which had an effective lending capacity of 440 billion euros, was an additional counter-crisis measure that was executed under international law. The European Financial Stabilization Mechanism (EFSM) was a response to the crisis instituted under European law that was based upon Article 122(2) of the Treaty on the Functioning of the European Union (TFEU) ${ }^{17}$.

Loans to Greece were made conditional upon the implementation of economic austerity and structural reform programs ${ }^{18}$. As the crisis spread to Cyprus, Ireland, Portugal and Spain, demands were made on the crisis hit countries to lower wage costs, cut social services and implement privatisation ${ }^{19}$. There is a strong argument that the implementation of austerity and structural reform programs compromised the sovereignty of these crisis hit nations.

Yanis Varoufakis, the Greek Minister for Finance from January to July 2015, has described the EFSF rescue package as 'toxic ${ }^{20}$. Varoufakis argued that the structure of the EFSF program ensured that every time a member state dropped out of the bond market, the burden imposed on 'marginal member states' would rise and the 'dynamic of contagion' would be provided a fresh impetus ${ }^{21}$. The combination of the pro-cyclical austerity measures, with the rescue packages, Varoufakis concluded, pushed down the expected and actual GDP growth rates of impacted member states ${ }^{22}$.

\section{Process of Reform}

Following the spread of the sovereign debt crisis to Italy and Spain, where refinancing costs had skyrocketed, the view had developed that Europe would not be able to withstand the crisis through the readjustment of existing government

\footnotetext{
${ }^{13}$ Herrmann, 2013, above n 5, p.26.

${ }^{14}$ Ibid, Hermann 2013, p.27.

${ }^{15}$ Ibid, Hermann 2013, p.27.

${ }^{16}$ Ibid, Hermann 2013, p.26.

${ }^{17}$ Council Regulation (EU) 407/2010 of 11 May 2010 Establishing a European Financial Stabilisation Mechanism [2010] OJ L 118/ 1.

${ }^{18}$ Herrmann, 2013, above n 5, p.27.

${ }^{19}$ Bjorn Hacker, On the Way to a Fiscal or a Stability Union? (December 2013) Friedrich Ebert Stiftung, 2. $\measuredangle$ tttp://library.fes.de/pdf-files/id/ipa/10400.pdf>

${ }^{20}$ Yanis Varoufakis, 'From Contagion to Incoherence Towards a model of the Unfolding Eurozone Crisis' (2013)

32 Contributions to Political Economy 51, p.57.

${ }^{21}$ Ibid, Varoufakis, 2013, p.63.

${ }^{22}$ Ibid, Varoufakis, 2013, p.65.
} 
instruments ${ }^{23}$. The election of Francois Hollande as President of France in 2012, provided additional impetus to those, including the Italian Prime Minister, Mario Monti, who opposed the implementation of austerity measures in response to the crisis. ${ }^{24}$ At their meeting on 26 October 2011, the governments of the euro Member States asked the President of the European Council, Herman Van Rompuy, to identify possible steps to 'strengthen the economic union to make it commensurate with the monetary union'. ${ }^{25}$ It was requested that the report focus upon 'strengthening economic convergence within the Eurozone, improving fiscal discipline' and exploring 'the possibility of limited Treaty changes. ${ }^{26}$ The 'Four Presidents' Report', ${ }^{27}$ written by Van Rompuy, in consultation with the Presidents of the European Commission, Eurogroup and ECB was produced as a consequence of this request. ${ }^{28}$

The appeal for the creation of the Four Presidents' Report provided acknowledgement that the European sovereign debt crisis was not due solely to the transgressions of individual nations against European regulations. ${ }^{29}$ The source and spread of the European sovereign debt crisis has been recognised to be a consequence, at least in part, to the 'flawed original design of the euro' ${ }^{30}$ The fragility of the union under crisis was not understood and the incremental multi-country crisis management that was implemented as a reaction to the crisis was 'messy' and was a destabilising factor during the course of the crisis. ${ }^{31}$ The secondary law responses, including the 'European Semester', the 'Six-Pack', the 'Two-Pack', the 'Euro-Plus Pact' and the 'Fiscal Compact' could all be viewed as 'piecemeal tinkering with the existing architecture of the Eurozone ${ }^{32}$.

\section{Reports Leading up to the Four Presidents' Report}

A number of reports were produced subsequent to October 2011, leading up to the publication of the final Four Presidents' Reports in December 2012:

In June 2012 Van Rompuy presented his first report for deepening European integration. ${ }^{33}$ The report proposed the implementation of a banking union that would be propped up by the European Stability Mechanism (ESM). ${ }^{34}$ The report also discussed the need for a fiscal union with the option of joint issuing of debt securities. ${ }^{35}$ The proposals for increasing 'communisation' met opposition from states, such as Finland, that backed the austerity policies supported by the German government'. 36

- In October 2012, Van Rompuy, presented an interim report, following individual talks with Member State governments and the President of the

\footnotetext{
${ }^{23}$ Ibid, Hacker, 2013, p.2.

${ }^{24}$ Ibid, Hacker, 2013, p.2.

${ }^{25}$ Euro Summit, Euro Summit Statement (26 October 2011), 10

বhttp://www.consilium.europa.eu/uedocs/cms_Data/docs/pressdata/en/ec/125644.pdf>.

${ }^{26}$ Ibid, Euro Summit, 2011, 10.

${ }^{27}$ Herman Van Rompuy et al, Towards a Genuine Economic and Monetary Union (5 December 2012).

${ }^{28}$ Hacker, 2013, above n 19, 2.

${ }^{29}$ Ibid, Hacker, 2013, 2.

${ }^{30}$ Lane, 2012, above n 4, p.65.

${ }^{31}$ Ibid, Lane, 2012, p.65.

${ }^{32}$ Hacker, 2013, above n 19, 2.

${ }^{33}$ Herman Van Rompuy et al, Towards a Genuine Economic and Monetary Union (26 J une 2012).

${ }^{34}$ Van Rompuy et al, 2012, above n 33, pp.4-5; Hacker, 2013 above n 19, 3.

${ }^{35}$ Van Rompuy et al, 2012 above n 33, pp.5-6; Hacker, 2013 above n 19, 3.

${ }^{36}$ Hacker, 2013, above n 19, 3.
} 
European Parliament. ${ }^{37}$ The proposal for a banking union was retained with the proviso that there must be more effective fiscal discipline to counter the moral hazard resulting from the taking over of the banking sector. ${ }^{38}$ A central budget was also proposed with which 'a form of limited fiscal solidarity' would be enabled through 'elements of fiscal risk sharing. 39

- $\quad$ On 28 November 2012, a 'Blueprint for a Deep and Genuine Economic and Monetary Union' was presented by the European Commission. 40 The Blueprint proposed that within six to18 months the banking union should be realised. ${ }^{41}$ Beyond 18 months to five years, further budgetary and fiscal policy coordination was proposed through a 'proper fiscal capacity for the Eurozone, a redemption fund and the common issuance of short-term government debt (eurobills). ${ }^{42}$ Beyond five years it was proposed that autonomous Eurozone budgeting should be established for the EMU that could absorb economic shocks and that 'fiscal policy conditions for the common issuance of public debt' (Eurobonds) should be implemented. ${ }^{43}$

\section{The Four Presidents' Report}

The Four Presidents' Report was presented at the meeting of the European Council on 13-14 December 2012. ${ }^{44}$ The report presented a 'time bound three-stage plan' to realise a 'genuine EMU'. ${ }^{45}$ The Four Presidents' Report aimed to achieve closer integration in four principal areas including:

- banking union; 46

- closer integration of budgetary policies, including a potential further budgetary capacity at the Eurozone level and a common debt instrument (eurobills); 47

- better coordination of economic policies other than fiscal policy; 48 and

- strengthening democratic legitimisation and accountability, potentially resulting in a degree of political union. 49

While the actions proposed in the Four Presidents' Report were ambitious, significant progress was only made with proposed measures relating to the banking union. ${ }^{50}$ Subsequent to the Four Presidents' Report, agreements were made with regards to the:

\footnotetext{
${ }^{37}$ Herman Van Rompuy et al, Towards a Genuine Economic and Monetary Union: Interim Report (12 October 2012).

${ }^{38}$ Van Rompuy et al, 2012, above n 37, 4-5; Hacker, 2013, above n 19, 4.

${ }^{39}$ Van Rompuy et al, 2012, above n 37, 4; Hacker, 2013, aboven 19, 4.

${ }^{40}$ European Commission, A Blueprint for a Deep and Genuine Economic and Monetary Debate, Launching a European Debate (28 November 2012).

${ }^{41}$ European Commission, 2012, above n 40, 12; Hacker, 2013, above n 19, 6.

${ }^{42}$ European Commission, 2012, above n 40, 12; Hacker, 2013, above n 19, 6.

${ }^{43}$ European Commission, 2012, above n 40, 12-13; Hacker, 2013, above n $19,6$.

${ }^{44}$ Hacker, 2013, above n 19, 6.

${ }^{45}$ Van Rompuy et al, 2012, above $\mathrm{n} 33,2$.

${ }^{46}$ Ibid, Van Rompuy et al, 2012, 5-8.

${ }^{47}$ Ibid, Van Rompuy et al, 2012, 8-12.

${ }^{48}$ Ibid, Van Rompuy et al, 2012, 13-16.

${ }^{49}$ Ibid, Van Rompuy et al, 2012, 16-17.

${ }^{50}$ Iain Begg, What does the Five Presidents' Report mean for the Future of the Euro? (J une 2015)The London School of Political Sciences <http://blogs.lse.ac.uk/europpblog/2015/06/23/what-does-the-five-presidents-report-mean-forthe-future-of-the-euro/>.
} 
- prudential supervision of banks through the single supervisory mechanism (SSM); and

- common approach to resolve failing banks via the single resolution mechanism (SRM). ${ }^{51}$

It is submitted that the Four Presidents' Report did not deliver upon the goal of strengthening the economic union to a level commensurate to the monetary union. The Four Presidents' Report was not able to bring about a 'clear commitment to the medium-term establishment of a fiscal union'. ${ }^{52}$ The establishment of a fiscal capacity for the monetary union was scrapped at the summit meeting in December 2012 due to opposition from a group of nations, including Germany, ${ }^{53}$ The opportunity that was provided by the European sovereign debt crisis to implement the reforms necessary for a stable monetary union was not capitalised upon. ${ }^{54}$

\section{The Five Presidents' Report}

The Five Presidents' Report builds upon the earlier reports previously described and aims to achieve progress towards a deeper EMU on four fronts including a:

- Genuine Economic Union that ensures that each economy within the Union possesses the structural features required to prosper within the Monetary Union; 55

- Financial Union that guarantees the integrity of the euro and increases risk-sharing with the private sector; ${ }^{56}$

- Fiscal Union that provides fiscal sustainability and stabilisation; 57 and

- Political Union that provides a basis for progress on the above fronts through 'democratic accountability, legitimacy and institutional strengthening'.58

The aims of the Five Presidents' Report are proposed to be accomplished in three stages:

- Stage 1 measures, which are to be completed by 30 June 2017, are characterised as 'immediate steps' ${ }^{59}$ Actions are proposed that will boost 'competitiveness and structural convergence', complete the Financial Union, achieve and maintain 'responsible fiscal policies' at the national and euro level and enhance democratic accountability. ${ }^{60}$

- Stage 2 measures, which are to be completed by 2025 at the latest, are described as 'concrete measures of a more far-reaching nature' which would 'complete the EMU's economic and institutional architecture'. ${ }^{61}$

\footnotetext{
${ }^{51}$ Ibid, Begg, 2015.

${ }^{52}$ Hacker, 2013, above n 19, 7.

${ }^{53}$ Ibid, Hacker, 2013, 7.

${ }^{54}$ Lane, 2012, above n 30, 68.

${ }^{55}$ J uncker et al, 2015, above n 1, 4.

${ }^{56}$ Ibid, J uncker et al, 2015, 4.

${ }^{57}$ Ibid, J uncker et al, 2015, 5.

${ }^{58}$ Ibid, J uncker et al, 2015, 5.

${ }^{59}$ Ibid, J uncker et al, 2015, 5.

${ }^{60}$ Ibid, J uncker et al, 2015, 5.

${ }^{61}$ Ibid, J uncker et al, 2015, 5.
} 
- It is envisaged in the report that when the Final Stage is reached, 'a deep and meaningful EMU would provide a stable and prosperous place' for all the citizens of the EU member states that share the euro, and which would be attractive for other EU member states to join if they are ready to do so. ${ }^{62}$

It is beyond the scope of this essay to analyse all of the measures proposed in the Five Presidents' Report. The proposals to create a European Deposit Insurance Scheme (EDIS), a European Fiscal Board (EFB) and a Eurozone Treasury are analysed in the following sections.

\section{European Deposit I nsurance Scheme}

The EDIS is described in the Five Presidents' Report as the third pillar of a fullyfledged banking union. ${ }^{63}$ The primary aim of the Banking Union is to break the link between a Member State's banks and its taxpayers'. ${ }^{64}$ The Banking Union reforms seek to prevent a declining bank sector from jeopardising the sustainability of public debt or unsustainable public debt compromising an otherwise solvent bank sector. ${ }^{65}$ As previously discussed, the first two pillars of the banking union, the SSM and the SRM have already been implemented to respectively provide a common framework for the supervision of banks and bank resolution.

The aim of the EDIS is to provide a 'stronger and more uniform degree of insurance cover for all retail depositors in the banking union' such that a bank's location should not determine the level of depositor confidence in that bank. ${ }^{66}$ As stated by Goyal et al of the IMF, losses of confidence can quickly flow 'if a weak sovereign is perceived not to be able to honour its safety net obligations, triggering capital flight and deposit outflows' ${ }^{67}$ Deposit Guarantee Schemes are designed to limit the possibility of systemic bank runs. ${ }^{68}$ Deposits of up to $€ 100,000$ are already protected through National Deposit Guarantee Schemes (NDGS). ${ }^{69}$ The Deposit Guarantee Scheme Directive 2014/49/EU requires all deposit-taking banks in the EU to be a member of a NDGS. ${ }^{70}$ However these NDGSs are considered to be vulnerable to large local shocks. ${ }^{71}$

The United States is an example of a monetary union where private financial connections across state borders have helped to cushion regional economic impacts. ${ }^{72}$ In smoothing the business cycle, private risk sharing across states has proven to be as important as fiscal risk sharing. ${ }^{73}$ However in the Eurozone, cross-border ownership

\footnotetext{
${ }^{62}$ Ibid, J uncker et al, 2015, 5.

${ }^{63}$ Ibid, J uncker et al, 2015, 11.

${ }^{64}$ European Commission, Towards a European Deposit Insurance Scheme (9 November 2015) 1

$\varangle$ ttp://ec.europa.eu/epsc/pdf/publications/5p_note_edis.pdf >.

${ }^{65}$ Ibid, European Commission, 2015, 1.

${ }^{66}$ Ibid, European Commission, 2015, 1.

${ }^{67}$ Goyal et al, A Banking Union for the Euro Area (February 2013) International Monetary Fund Staff Discussion

Note, 19 <https://www.imf.org/external/pubs/ft/sdn/2013/sdn1301.pdf>.

${ }^{68}$ European Commission, 2015, above n 64, 1.

${ }^{69}$ Ibid, European Commission, 2015, 1.

${ }^{70}$ Directive 2014/ 49/ EU of the European Parliament and of the Council of 16 April 2014 on Deposit Guarantee

Schemes [2014] OJ L 173/49.

${ }^{71}$ European Commission, A European Deposit Insurance Scheme (EDIS) - Frequently Asked Questions, 3 (24

November 2015) <http://europa.eu/rapid/press-release_MEMO-15-6153_en.htm>.

${ }^{72}$ Christian Odenhall, The Eurozone's Five Presidents' Report': An Assessment (22 J une 2015) Centre for

European Reform < https://www.cer.org.uk/insights/eurozones-five-presidents-report-assesment>.

${ }^{73}$ Ibid, Odenhall, 2015.
} 
and capital flows are underdeveloped which in turn means that private risk-sharing is underdeveloped. ${ }^{74}$ Additionally as banks as so closely tied to their regional economy and their sovereign, rather than being a stabilising factor, they can destabilise the government and the economy during an economic downturn. ${ }^{75}$

The EDIS is proposed to be implemented over three stages. ${ }^{76}$ The first stage from 2017 to 2019 is termed the reinsurance phase. In this stage a NDGS would only be able to access the EDIS after it has exhausted its own resources. ${ }^{77}$ In the co-insurance phase, which is designed to run from 2020-2023, participating NDGSs will be coinsured by the EDIS. ${ }^{78}$ The co-insurance phase is different from the reinsurance phase in that funding is provided and loss is covered from the first euro deposited into an account. ${ }^{79}$ The share of the insurance coverage borne by the EDIS will gradually increase over the co-insurance period from 20 to 80 per cent. As of 2024, during the full insurance period, the participating NDGSs would be fully insured by the EDIS. ${ }^{80}$

The EDIS proposal has garnered criticism from sources including Ludger Schuknecht, the chief economist of the German Federal Ministry of Finance, who stated that the EDIS is an 'insurance scheme that only ensures problems'. ${ }^{81}$ Schuknecht has condemned the scheme for providing the wrong incentives to national-level politicians who could 'suspend their insolvency regimes and asset seizure rules without being punished'. ${ }^{82}$ Schuknecht argues that as a consequence of the EDIS 'other countries would soon be liable for the consequences of misguided domestic policies, without those countries being able to influence such behaviour'. ${ }^{83}$

Schuknecht also argues that through the EDIS, 'the door would be opened for further centralisation and mutualisation in Europe'. ${ }^{84}$ Schuknecht claims that it is 'somewhat far-fetched to claim that the EDIS is connected to the internal market'. ${ }^{85}$ Article 114 of the TFEU provides that the European Parliament and the Council shall act in accordance with the ordinary legislative procedure... for the approximation of... provisions laid down by law... which have as their object the establishment and functioning of the internal market'. ${ }^{86}$ It is Schuknecht's contention that the legal basis allows individual countries to be outvoted such that 'supposed or actual unilateral burden-sharing can be forced through. ${ }^{87}$

\footnotetext{
${ }^{74}$ Ibid, Odenhall, 2015.

${ }^{75}$ Ibid, Odenhall, 2015.

${ }^{76}$ European Parliament, European Deposit Insurance Scheme: Completing the Banking Union (14 March 2016),

$4 \measuredangle \mathrm{http}: / /$ www.europarl.europa.eu/thinktank/en/document.html?reference=EPRS_BRI(2016)579090>.

${ }_{77}^{77}$ Ibid, European Parliament, 2016, 4.

${ }^{78}$ Ibid, European Parliament, 2016, 5,6.

${ }^{79}$ Ibid, European Parliament, 2016, 5,6.

${ }^{80}$ Ibid, European Parliament, 2016, 6.

${ }^{81}$ Ludger Schuknecht, 'An Insurance Scheme That Only Ensures Problems' Frankfurter Allgemeine (online) 8

February 2016 <http://blogs.faz.net/fazit/2016/02/08/an-insurance-scheme-that-only-ensures-problems-7298/>.

${ }^{82}$ Ibid, Schuknecht, 2016.

${ }^{83}$ Ibid, Schuknecht, 2016.

${ }^{84}$ Ibid, Schuknecht, 2016.

${ }^{85}$ Ibid, Schuknecht, 2016.

${ }^{86}$ Treaty on the Functioning of the European Union, opened for signature 13 December 2007 (entered into force 1 December 2009) art 114.

${ }^{87}$ Schuknecht, 2016, above n 81.
} 
Schuknecht also claims that the plans for the EDIS are 'yet another sign of how little the subsidiary principle is taken seriously'. ${ }^{88}$ Article 5 of the Treaty on European Union established the principle of subsidiarity ${ }^{89}$ Under the principle of subsidiarity:

in areas which do not fall within its exclusive competence, the Union shall act only if and in so far as the objectives of the proposed action cannot be sufficiently achieved by the Member States... but can be better achieved at Union Level. ${ }^{90}$

However, it is noted that the internal market legal basis was used for the approval of the SRM Regulation in 2014. ${ }^{91}$ Schuknecht's argument would appear to be contradicted by Germany's earlier support of the SRM.

There are other flaws in the argument put forward by Schuknecht. The EDIS will not present the level of moral hazard that Schuknecht suggests that it will pose. As the EDIS will only guarantee deposits up to a limit of $€ 100,000$, it is unlikely that a government would want to trigger a bank failure. ${ }^{92}$ As conceded by Schuknecht the EDIS would mean that 'central banks would not have to jump in with emergency liquidity assistance quite as quickly' which should impose more discipline on bank creditors and policymakers. ${ }^{93}$

It is submitted that the proposal in the Five Presidents' Report to complete the banking union by way of the EDIS is an ambitious goal that should be admired. As argued by Goyal et al, without the EDIS, the banking union would remain an incomplete and risky construct that fails to delink the funding costs of weak sovereigns from that of their banks'. ${ }^{94}$ The EDIS is a crucial step in the process of decoupling banks from their sovereign, ensuring that banks and capital markets are diversified across the monetary union and that the monetary union is more resilient. ${ }^{95}$ The approval of the SRM Regulation in 2014 demonstrates that the internal market legal basis is appropriate for the implementation of the EDIS.

\section{European Fiscal Board}

The Five Presidents' Report highlighted that one of the main lessons of the European sovereign debt crisis was that 'fiscal policies are a matter of vital common interest in a Monetary Union'. ${ }^{96}$ It is noted that in the past twenty years, the average ratio of public debt to GDP in the Eurozone has risen from 70 per cent before the crisis to 90 per cent in $2016 .^{97}$ Consequently there is a greater likelihood today that a problem in one Member State could spill over to other nations. ${ }^{98}$ If the overall direction of fiscal policy for the entire Eurozone is not suitable, Member States may still suffer in spite of their own responsible fiscal policies. ${ }^{99}$

\footnotetext{
${ }^{88}$ Ibid, Schuknecht, 2016.

89 Treaty on European Union, opened for signature 7 February 1992 (entered into force 1 November 1993) art 5.

90 Ibid, Treaty on European Union, art 5.

${ }^{91}$ Nicolas Veron, European Deposit Insurance: A Response to Ludger Schuknecht (16 February 2016) Bruegel

<http:// bruegel.org/ 2016/ 02/ european-deposit-insurance-a-response-to-ludger-schuknecht/ >.

92 Ibid, Veron, 2016.

93 Ibid, Veron, 2016.

94 Goyal et al, 2013, above n 67, 19.

95 Odenhall, 2015, above $\mathrm{n} 72$.

96 J uncker et al, 2015, above n 1, 14.

${ }^{97}$ European Commission, Completing Europe's Economic and Monetary Union: An Advisory European Fiscal

Board (2016) $1<$ <ttps:// ec.europa.eu/priorities/ sites/ beta-political/files/ factsheet-efb_en.pdf>.

${ }^{98}$ Ibid, European Commission, 2016, 1.

99 Ibid, European Commission, 2016, 1.
} 
Articles 2(3), 3, 4 and 5 of the TFEU dictate that Member States are responsible for the formulation and execution of economic and fiscal policies. Additionally, Articles 119, 120 and 121 of the TFEU provide a mechanism for the positive integration of the various Member State fiscal policies. Under Article 121 the performance of Member States is monitored by the Commission, which then reports to the Council. Article 126 of the TFEU dictates the sanctions that apply when a Member State violates the rules relating to sustainable public finances.

The two main objectives of the European fiscal framework are:

- to discourage the deficit bias of governments such that the long-term sustainability of public debt is ensured; and

- to enable counter-cyclical fiscal policy. ${ }^{100}$

With regards to the second objective, researchers including Barbiero and Darvas, ${ }^{101}$ have concluded that the fiscal stance taken since 2012 has been too restrictive given the economic situation in the Eurozone. ${ }^{102}$ In a recession, undue fiscal consolidation, through such means as austerity measures, can prolong economic weaknesses, keep the debt ratio high and trigger further fiscal consolidation. ${ }^{103}$

It is against this backdrop, in line with the recommendations contained in the Five Presidents' Report, the EFB will be put into operation by the European Commission as an 'advisory body on the overall direction of fiscal policy' in the Eurozone. ${ }^{104}$ The Commission has stated that the EFB is to be composed of 'five renowned international experts with credible competence and experience in macroeconomics and practical budgetary policy-making. ${ }^{105}$ The EFB will act as an 'independent evaluator of how the EU's fiscal framework is being implemented' and will 'feed' into the Commission's work of monitoring the enforcement of the Stability and Growth Pact (SGP). ${ }^{106}$ It will not be the role of the EFB to replace national fiscal councils, which are a requirement of the two-pack legislation, or to duplicate the Commission's work on applying the SGP. ${ }^{107}$

The European Commission's proposal for the creation of the EFB has proven to be controversial. The Eurogroup President J eroen Dijsselbloem and the German finance minister, Wolfgang Schauble, have criticised the Commission's plans for the EFB. ${ }^{108}$ Dijsselbloem has argued that the EFB's set up does not have an adequate level of independence. ${ }^{109}$ Schauble has stated that the EFB should not be an advisory body, but should be the ultimate decision-maker on national budgets. ${ }^{110}$ It is submitted that the views of Dijsselbloem and Schauble are of merit and that the EFB will not

\footnotetext{
100 Gregory Claeys et al, A Proposal to Revive the European Fiscal Framework (March 2016) Bruegel, 16 <http:// bruegel.org/ 2016/ 03/ a-proposal-to-revive-the-european-fiscal-framework/ >.

${ }^{101}$ Francesca Barbiero and Zsolt Darvas, In Sickness and in Health: Protecting and Supporting Public Investment in Europe Bruegel <http:// bruegel.org/ 2014/ 02/ in-sickness-and-in-health-protecting-and-supporting-publicinvestment-in-europe/ $>$.

102 Claeys et al, 2016, above n 100, 16.

103 Ibid, Claeys et al, 2016, 16.

104 European Commission, 2016, above n 97, 1.

105 Ibid, European Commission, 2016, 2.

106 Ibid, European Commission, 2016, 2.

107 Ibid, European Commission, 2016, 2.

108 Gabriele Steinhauser, 'Not All on Board with the European Fiscal Board' The Wall Street J ournal (online) 13 November $2015<$ http:/ / blogs.wsj.com/ brussels/ 2015/ 11/ 13/ not-all-on-board-with-the-european-fiscal-board/ > . 109 Ibid, Steinhauser, 2015.

110 Ibid, Steinhauser, 2015.
} 
have enough power or independence to make significant progress towards achieving both objectives of the European fiscal framework.

It is put forward that the EFB is likely to be viewed in the same light as the European Commission, which may diminish the regard that is given to the EFB's recommendations. As argued by Mody, the political process undermines the proper application of any fiscal policy. ${ }^{111}$ Currently there is a perception amongst some stakeholders that the European Commission does not always provide unbiased recommendations to the Council. ${ }^{112}$ Although Article 4 of the Commission's decision to establish the EFB states that the 'EFB shall act independently', 113 the role of the $\mathrm{EFB}$ is advisory and the nomination of members depends almost entirely upon the Commission. $^{114}$

The lack of transparency regarding the reasoning behind the advice provided by the EFB is also a cause of concern. ${ }^{115}$ Article 6 of the Commission's decision to establish the EFB states that the EFB is only required to publish one annual report. ${ }^{116}$ It is submitted that the EFB would gain more legitimacy if it is required to publish the justification for its advice at much shorter intervals.

A truly independent body should be given the duty to implement the objectives of the European fiscal framework. The creation of the EFB may help to ensure that existing fiscal rules are followed that aim to achieve long-term public debt sustainability. However, it is doubtful whether the EFB will have enough independence and power to make meaningful progress towards the counter-cyclical fiscal policy objective, where reforms may be required that do not conform with current practices. It is submitted that Article 121 of the TFEU needs to be amended such that the EFB takes on the role of monitoring and reports directly to the Council, rather than through the Commission.

\section{Eurozone Treasury}

The Five Presidents' Report states that 'as the Eurozone evolves towards a genuine EMU, some decisions will increasingly need to be made collectively'. ${ }^{117}$ The report asserts that more joint decision-making on fiscal policy will be required for a genuine Fiscal Union. ${ }^{118}$ A future Eurozone Treasury is proposed as a place for such collective decision making. ${ }^{119}$ However the report emphasises that Eurozone Member States would continue to be responsible for making decisions on taxation and the allocation of budgetary expenditures according to their preferences and political choices. ${ }^{120}$

\footnotetext{
${ }^{111}$ Ashoka Mody, Are the Eurozone's Fiscal Rules Dying? (29 October 2014) Bruegel $<\mathrm{http}$ // / bruegel.org/ 2014/ 10/ are-the-eurozones-fiscal-rules-dying/ >.

112 Claeys et al, 2016, above n 100, 15.

113 Commission Decision (EU) 2015/ 1937 of 21 October 2015 on Establishing an Independent Advisory European Fiscal Board [2015] OJ L 282/37 art 4.

114 Claeys et al, 2016, above n 100, 16.

115 Ibid. Claeys et al, 2016, 16.

116 Commission Decision (EU) 2015/ 1937 of 21 October 2015 on Establishing an Independent Advisory European Fiscal Board [2015] OJ L 282/37 art 6.

117 J uncker et al, 2015, above n 1, 18.

118 Ibid, J uncker et al, 2015, 18.

119 Ibid, J uncker et al, 2015, 18.

120 Ibid, J uncker et al, 2015, 18.
} 
The push to form a Eurozone Treasury has been supported by two of Europe's most powerful central bankers. ${ }^{121} \mathrm{~J}$ ens Weidmann, president of the Deutsche Bundesbank, and Francois Villeroy de Galhau, Governor of the Bank of France, have urged the 19 Member States of the Eurozone to move towards a 'comprehensive sharing of sovereignty' which would include a 19 member treasury. ${ }^{122}$ The pair stated that 'while monetary policy has delivered a lot of support for the Eurozone economy, it cannot bring about long-lasting economic growth'. ${ }^{123}$ They argued that 'more integration appears to be the most straightforward solution to restore confidence in the Eurozone'. ${ }^{124}$

The comments are a rare demonstration of unity from leading French and German figures, nations that have often diverged regarding their visions for the Eurozone. ${ }^{125}$ Germany has for a long time advocated that budgetary discipline is at the heart of a fiscal union. ${ }^{126}$ In contrast, France has supported a more flexible investment-led approach where the creation of new institutions is prioritised to bolster governance. ${ }^{127}$ It is noted, however, that efforts to create a Eurozone Treasury will likely be resisted by those countries that oppose transferring more sovereignty to EU institutions. ${ }^{128}$

The French Economy Minister, Emmanuel Macron, supports the creation of a common treasury which would be overseen by a separate Eurozone parliament'. ${ }^{129}$ The French Minister argued that 'if we don't move forward, we decide for dismantling the Eurozone,. ${ }^{130}$ Macron stated that he would like a common Eurozone Treasury to be set up by member states with a single finance minister. ${ }^{131}$ Contributions would then be made by Member States through part of their VAT receipts and unemployment insurance to fund transfers, with a Eurozone parliament acting as a political check. ${ }^{132}$ Macron has expressed scepticism that the Five Presidents' recommendation for a Eurozone Treasury will lead to any concrete action. ${ }^{133}$

It is submitted that too little focus was placed upon the formation of a Eurozone Treasury in the Five Presidents' Report. While the report flagged the creation of a Eurozone Treasury, it did not provide any detail about how this aim could be achieved and what treaty reforms would be required. ${ }^{134}$ There should have been a commitment in the report to at least have an expert group look into the design and legal requirements for a Eurozone treasury. ${ }^{135}$

\footnotetext{
${ }^{121}$ Mehreen Kahn, 'Franco-German Central Bankers Call for Creation of Eurozone Treasury', The Telegraph (online) 8 February 2016 <http://www.telegraph.co.uk/finance/economics/12146298/Franco-German-central-bankerscall-for-creation-of-eurozone-treasury.html $>$.

${ }^{122}$ Ibid, Khan, 2016.

${ }^{123}$ Ibid, Khan, 2016.

${ }^{124}$ Ibid, Khan, 2016.

${ }^{125}$ Ibid, Khan, 2016

${ }^{126}$ Ibid, Khan, 2016.

${ }^{127}$ Ibid, Khan, 2016.

${ }^{128}$ Ibid, Khan, 2016.

${ }^{129}$ Ferdiando Giugilano and Sarah Gordon, 'Macron Calls for Radical Reform to Save Euro', Financial Times (online) 24 September 2015 < https://next.ft.com/content/6d327720-62c5-11e5-a28b-50226830d644>.

${ }^{130}$ Ibid, Giugilano and Gordon, 2015.

${ }^{131}$ Ibid, Giugilano and Gordon, 2015.

132 Ibid, Giugilano and Gordon, 2015.

133 Ibid, Giugilano and Gordon, 2015.

${ }^{134} \mathrm{~J}$ uncker et al, 2015, above n 1, 18.

135 Ibid, J uncker et al, 2015, 14.
} 


\section{Overall Assessment of the Five Presidents' Report}

The actions proposed in the Five Presidents' Report are less ambitious than those proposed in the Four Presidents Report. ${ }^{136}$ Given the failure of the Four Presidents Report to lead to concrete actions, other than the SSM and the SRM, this was probably a calculated move. In light of the advances made from the Four Presidents' Report with regards to the banking union, the proposal in the Five Presidents' Report to complete the banking union through the implementation of an EDIS is considered to be a positive step to break the link between banks and sovereigns. However, given Germany's opposition to the scheme, it would appear to be a difficult path ahead for such a scheme to be implemented.

The Five Presidents' Report fails to accept and push the debate regarding the necessity for treaty change. ${ }^{137}$ The report, consequently does not honour the mandate that was originally provided to Van Rompuy in October 2011 to explore the possibility of treaty change. The report does not acknowledge for which of its proposed actions treaty amendments will be required. In contrast, the European Commission's Blueprint for a Deep and Genuine EMU of 2012 clearly described for which of its proposed actions treaty amendments would be required. ${ }^{138}$

The Five Presidents Report should have placed counter-cyclical policy at the centre of its recommendations on fiscal matters, and urged policy-makers to review the Eurozone's current fiscal rules. ${ }^{139}$ It is acknowledged that the report recognises that fiscal policy needs to be set counter-cyclically at the national and Eurozone level. ${ }^{140}$ However, rather than placing an emphasis on counter-cyclical policy, actions in the report are focussed upon strengthening existing fiscal rules aimed at debt reduction. ${ }^{141}$

The ECB's role as a lender of last resort is not mentioned in the Five Presidents' Report. Given the controversial nature of this subject in countries such as Germany, and the success of the Outright Monetary Transactions (OMT) program, the absence of this subject from the Five Presidents' Report is not of concern. ${ }^{142}$

\section{Conclusion}

The European sovereign debt crisis exposed the fragility of the Eurozone. While the Five Presidents' Report aims to prevent a similar crisis from occurring in the future, it is submitted that the measures proposed do not go far enough towards establishing financial stability in the Eurozone. In particular, a key criticism of the report has been that counter-cyclical policy has not been the focus of the report's recommendations on fiscal matters. Ideally, the report should have presented a clear road map regarding what legal reforms are necessary to ensure the financial stability of the EMU. The consequence of the limited success of the Four Presidents' Report to

\footnotetext{
${ }^{136}$ Begg, 2015, above n 50.

${ }^{137}$ Guntram Wolff, Euro Area Governance: An Assessment of the "Five Presidents" Report (24 J une 2015)

Bruegel <http://bruegel.org/2015/06/euro-area-governance-an-assessment-of-the-five-presidents-report/>.

${ }^{138}$ European Commission, 2012, above n 40.

${ }^{139}$ Odenhall, 2015, above $\mathrm{n} 72$.

${ }^{140}$ Ibid, Odenhall, 2015.

${ }^{141}$ Ibid, Odenhall, 2015.

${ }^{142}$ Ibid, Odenhall, 2015.
} 
deliver upon its mandate has resulted in the Five Presidents' Report being less ambitious in the actions it has proposed compared to its predecessor reports.

With regards to those proposed actions that have been analysed in this essay it is submitted that:

- the EDIS is an ambitious proposal, which should be supported. The EDIS is a crucial step in the process of de-coupling banks from their sovereign, ensuring that banks and capital markets are diversified across the monetary union and that the monetary union is more resilient. The approval of the SRM Regulation in 2014 demonstrates that the internal market legal basis is appropriate for the implementation of the EDIS.

- the creation of the EFB should help to ensure that existing fiscal rules are followed that aim to achieve long-term public debt sustainability. However, it is doubtful whether the EFB will have enough independence and power to make meaningful progress towards the counter-cyclical fiscal policy objective. It is submitted that Article 121 of the TFEU needs to be amended such that the EFB reports directly to the Council, rather than through the Commission. The reasoning behind the advice provided by the EFB should also be clear, transparent and reported to the public on a regular basis.

- a Eurozone Treasury is one means by which further integration and growth could be accomplished for the Eurozone. A future Eurozone Treasury would provide an avenue for joint decision making by the member states on fiscal policy. However not enough attention was focussed upon the legal reforms required to progress this initiative in the Five Presidents' Report.

In light of the European sovereign debt crisis, an opportunity was again missed by the Five Presidents' Report to bring about significant reform. However, it is recognised that a number of countries, including Germany, will oppose proposals that result in the transfer of power to EU institutions. This will likely be demonstrated with regards to the proposed implementation of the EDIS. Consequently, the measured approach taken in the Five Presidents' Report can be accepted as a strategic decision made to maintain momentum towards reforming the economic architecture of the Eurozone. 